\title{
Coupling effects of structure, oxygen availability and temperature on microbial growth in a pastry filling
}

\author{
Paula Mateos ${ }^{1}$, Amanda Laca*1, Adriana Laca ${ }^{1}$, Mario Díaz ${ }^{1}$
}

Edited by

Juan Carlos Salcedo-Reyes

salcedo.juan@javeriana.edu.co

1. Department of Chemical and Environmental Engineering. University of Oviedo. C/ Julián Clavería s/n. 33071 Oviedo. Spain.

*lacaamanda@uniovi.es

Received: 03-06-2020

Accepted: 05-05-2021

Published online: 09-08-2021

Citation: Mateos P, Laca A, Laca A, Díaz M. Coupling effects of structure, oxygen availability and temperature on microbial growth in a pastry filling, Universitas Scientiarum, 26(2): 229-242, 2021.

doi: 10.11144/Javeriana.SC26-2.ceos

Funding: Employment, Industry and Tourism Office of the Principality of Asturias (Spain) through project IDI/2018/000127.

Electronic supplementary material: n.a.

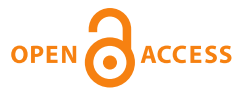

\begin{abstract}
The structure of real food is a key factor to be considered in order to control microbial growth. A pastry filling has been employed as model food to study the growth of Staphylococcus under different conditions. Additionally, the structure of the food system has been characterised by means of rheological measurements. Frequency sweeps showed that, in all cases, the elastic component determines the rheological behaviour of model pastry filling $\left(G^{\prime}>G^{\prime \prime}\right)$. Values obtained for the coordination number $(z)$ and the proportional coefficient $(A)$ indicated that the model food exhibits more aggregate structures and stronger links at lower temperatures. According to the maximum specific growth rates, the Staphylococcus growth in the model pastry filling was clearly conditioned by oxygen diffusion, which is limited by the food matrix, and also by the incubation temperature. In addition, the analysis of Staphylococcus growth at different temperatures suggested the influence of the pastry filling structure on microorganism behaviour.
\end{abstract}

Keywords: Microorganisms; food safety; pastry; rheology; Staphylococcus; structure

\section{Introduction}

With increasing globalization, food safety has become a major concern of governments, food industry and consumers. Indeed, foodborne diseases along with waterborne diseases are nowadays the more widespread public health problem, being responsible for the death of approximately 1.8 million people every year and entailing great economic losses (Baptista et. al, 2017). Hence, food safety remains as industry's number one priority (Chinyama, 2014).

Among the possible origins of foodborne illness, microbiological sources stand out for entailing a great risk to public health. Staphylococcus aureus is an extremely versatile opportunistic pathogen that has the ability to grow and produce heat-stable toxins in food products. Meat, eggs and dairy products, as well as cream-filled bakery products are examples of food involved in staphylococcal poisoning (Alhashimi et. al, 2017; Silva et al., 2017). S. aureus is often found as a commensal on skin, skin glands and mucous membranes; certainly, $30 \%$ to $50 \%$ of individuals are asymptomatic carriers. Therefore, the presence of these bacteria in food occurs frequently due to an inappropriate manipulation of food (Alhashimi et. al, 2017), including improper use of temperature during processing and conservation, cross contamination, poor personal hygiene and inadequate equipment (Rebouças et al., 2017).

The majority of real food are solid or semi-solid structured systems where microorganisms are located and constrained to grow as three-dimensional colonies inside the food matrix (Aspridou et. al, 2014; Baka et al., 2017). Due to diffusional limitations of oxygen and nutrients and 
accumulation of metabolic products, these cells could experience alterations in cell development, morphology and membrane permeability, which can modify the microorganism response to various environmental factors (affecting, for instance, the thermal inactivation tolerance or the antimicrobial resistance of the bacterium) (Aspridou et. al, 2014; Costello et al., 2018). Hence, food microstructure becomes a key factor in order to control the microbial growth in food, and thereby affects food safety in many ways.

Food model systems are an alternative for experimental data collection, where all physicochemical and structural parameters can be controlled, so results could be transferable to food products with similar properties (Aspridou et. al, 2014). Commonly the employed food model systems are homogeneous media with one single phase, composed by the addition of gelling agents, such as agar, in a nutrient broth, which not always mimic the characteristics of real food. As far as we know, very few studies that use more complex food models containing ingredients actually employed in risky foodstuffs have been carried out (Costello et al., 2018). In this work, a first approach to determine the effect of food microstructure on the growth of Staphylococcus in pastry products has been carried out. With this aim, three of the ingredients most frequently used in pastry products (margarine, egg yolk and sugar) have been employed to obtain a model pastry filling. Specifically, these are basic ingredients of the filling used to prepare "brazo de Fabiola", a Spanish dessert, and, usually this filling is not cooked. The structure of the food system was characterised by means of rheological measurements and the evolution of Staphylococcus in the media has been monitored with the aim of identifying the effect of the structure on microorganism growth at different conditions of storage.

\section{Materials and methods}

\subsection{Microorganism}

Staphylococcus warneri (CECT 236) supplied by the Spanish Collection of Type Cultures was used as model bacterium.

\subsection{Pastry filling preparation and inoculation}

The pastry filling consists of three ingredients: shell eggs, sugar and margarine (sunflower oil, water, palm and coconut oil, skimmed milk powder, salt ( $0.3 \%)$, aromas, potassium sorbate, citric acid, vitamins A, E and D and carotenes) (total fat content: $60 \mathrm{~g}$ per $100 \mathrm{~g}$ ) which were purchased at a local supermarket and employed before the ending of their "best-before date". The model food was prepared by mixing $100 \mathrm{~g}$ of sugar, $250 \mathrm{~g}$ of margarine and the preinoculum pellet resuspended in $20 \mathrm{~g}$ of raw egg yolk. The preinoculum was prepared from a refrigerated stock of Petri dishes as described in Sanchez et al. (2019). Sterile $12 \mathrm{~mL}$ syringe-bodies $(1.5 \mathrm{~cm}$ in diameter and $7.6 \mathrm{~cm}$ in length; HSW Norm-Ject) were packed with approximately $10 \mathrm{~g}$ of this inoculated medium, reaching inside $4 \mathrm{~cm}$ in height. Then, the syringes were closed by placing a cotton wool plug on the top and an aluminium foil sealed with Teflon ${ }^{\circledR}$ at the syringe tip (Noriega et al., 2010a; Sanchez et al., 2019). The initial concentration of microorganism was approximately $1 \times 10^{7} \mathrm{CFU} \mathrm{g}^{-1}$. All the procedure was carried out in sterile conditions.

The ingredients were not sterilised, for this reason a negative control (pastry filling without being inoculated) were also included in the study (data not shown). Control experiments were carried out at the three assayed temperatures and the microbial concentrations were in these cases always below $1 \times 10^{3} \mathrm{CFU} \mathrm{g}^{-1}$ (four order lower than the initial concentration of $S$. warneri). 


\subsection{Experimental conditions and sampling}

Syringes were incubated at different temperatures $\left(6^{\circ} \mathrm{C}, 20^{\circ} \mathrm{C}\right.$ and $\left.30^{\circ} \mathrm{C}\right)$ to simulate refrigeration and room temperatures. With the aim of evaluating the effect of oxygen availability, sampling was carried out by taking $1 \mathrm{~g}$ of the model pastry filling at two longitudinal positions of the syringe: $3.7 \mathrm{~cm}$ to $4.0 \mathrm{~cm}$ (surface) and $0.0 \mathrm{~cm}$ to $0.3 \mathrm{~cm}$ (bottom). All samples were taken in triplicate (from three different syringes). Each sample was transferred to stomacher bags containing $9 \mathrm{~mL}$ of sterile saline solution $(0.7 \% \mathrm{NaCl})$ and serial decimal dilutions of the saline solution were plated in triplicate onto Nutrient Broth Agar. Petri dishes were incubated at $30^{\circ} \mathrm{C}$ for $48 \mathrm{~h}$ before counting. All the procedures were carried out in sterile conditions.

\subsection{Characterisation of the structured media}

A HAAKE MARS II rotational rheometer (ThermoFisher Scientific) has been employed to carry out the rheological measurements using a plate/plate measuring system (PP60Ti) with a gap of $1 \mathrm{~mm}$. To allow the stresses induced during sample loading to relax, samples rested for at least $15 \mathrm{~min}$ before any measurement (Laca et al., 2010a). The frequency sweeps were carried out from $0.1 \mathrm{~Hz}$ to $10 \mathrm{~Hz}$ at a constant shear stress of $5 \mathrm{~Pa}$ (within the linear viscoelasticity range). Model foods were measured at different temperatures $\left(6^{\circ} \mathrm{C}, 15^{\circ} \mathrm{C}, 20^{\circ} \mathrm{C}, 25^{\circ} \mathrm{C}\right.$ and $\left.30^{\circ} \mathrm{C}\right)$. Analyses were conducted at least in triplicate.

\section{Estimation of maximum specific growth rate}

Maximum specific growth rate was obtained according the next equation:

$$
\frac{d x}{d t}=-\mu_{\max } x
$$

Therefore, the following linear function was fitted to the microbial growth data obtained from plate counting:

$$
\ln x=\ln x_{0}-\mu_{\max } t
$$

Where $x_{0}$ and $x$ are the microbial concentration in the medium at initial time and at $t$ time, respectively. Since this linear relation is exclusively valid during the exponential growth phase (when cells are dividing regularly by binary fission and the growth rate is proportional to microorganism concentration), only the data corresponding to the first part of the curve were employed for the fitting. The data were selected by means of the fitting goodness, i.e., those data that gave values of $r^{2}$ below 0.95 were assumed to be out of the exponential growth phase and were not considered.

\subsection{Statistical analysis}

Excel software was employed to carry out a one-way ANOVA with a $95 \%$ confidence interval to analyse the data.

\section{Results and discussion}

\subsection{Effect of temperature}

The model pastry filling prepared with eggs, margarine and sugar, as explained in Material and Methods section, resulted in an accurate medium for $S$. warneri growth at all the assayed temperatures (Figure 1). In all cases, the initial inoculum was in the order of magnitude of 
$1 \times 10^{7} \mathrm{CFU} \mathrm{g}^{-1}$. In the six days that the experiment lasted, the concentration of bacteria increased around two orders of magnitude in the surface of the syringes when they were incubated at $30^{\circ} \mathrm{C}$, achieving values higher than $1 \times 10^{9} \mathrm{CFU} \mathrm{g}^{-1}$. The bacterial growth was slightly lower at $20^{\circ} \mathrm{C}$ and at $6{ }^{\circ} \mathrm{C}$ microorganism concentration only increased in one order of magnitude. In this case, the maximum value, that was not over $1 \times 10^{8} \mathrm{CFU} \mathrm{g}^{-1}$, was achieved after $80 \mathrm{~h}$ of incubation. These results are not in accordance with those found by Ananou et. al (2018) who reported that when $S$. aureus was incubated in liquid yolk at refrigerated temperatures the concentration of viable bacteria remained constant during $96 \mathrm{~h}$. Similarly, and also in liquid yolk, Sanchez et al. (2019) found that the concentration of $S$. warneri was approximately the same during $72 \mathrm{~h}$ at $11^{\circ} \mathrm{C}$. This can be explained mainly by the different composition of the media, since the model pastry filling contained a high concentration of sugar that favoured microorganism growth. The effect of temperature on Staphylococcus growth are easily reflected by comparing the maximum specific growth rates $\left(\mu_{\max }\right)$ (Table 1). The values obtained for the surface of the food model at $6^{\circ} \mathrm{C}, 20^{\circ} \mathrm{C}$ and $30^{\circ} \mathrm{C}$ were $0.0209 \mathrm{~h}^{-1}, 0.0438 \mathrm{~h}^{-1}$ and $0.0573 \mathrm{~h}^{-1}$, respectively. According to ANOVA results, there were statistically significant differences between the $\mu_{\max }$ values obtained

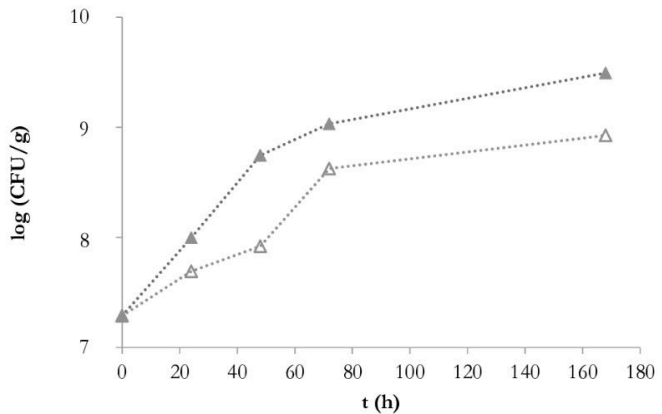

B)

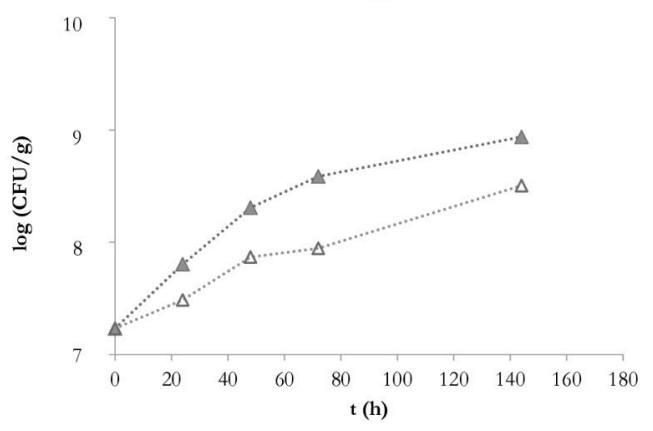

C)

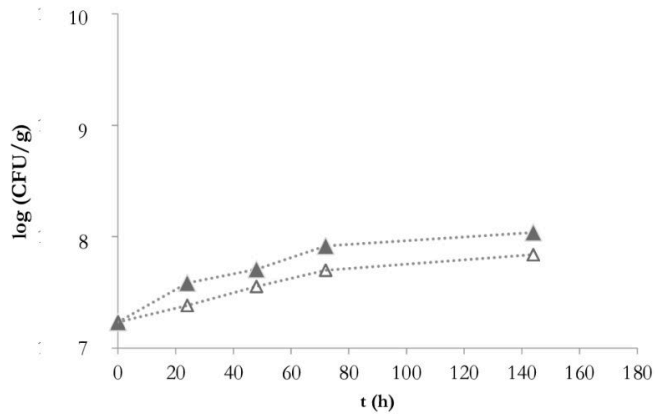

Figure 1. Growth of $S$. warneri in model pastry filling at different temperatures: A) $6{ }^{\circ} \mathrm{C}$, B) $20^{\circ} \mathrm{C}$ and C) $30^{\circ} \mathrm{C}$. Surface $(\triangle)$ and bottom $(\triangle)$ samples. In all cases, relative standard deviation $<5 \%$. 
for the different temperatures of incubation. Additionally, the maximum specific growth rates obtained at surface and bottom for each temperature studied were also significantly different $(95 \%$ confidence interval).

In addition, it should be pointed out that at all the analysed temperatures lag phase was not observed, although it might take place at the very first hours of incubation. Specifically, at room temperatures in only $24 \mathrm{~h}$ the bacterial concentration increased almost in one order of magnitude. It is evident the importance of storing this kind of pastry products at refrigerated conditions just after being prepared. However, it should be taken in mind that microbial growth is not inhibited even at refrigerated temperatures.

\section{Effect of oxygen availability}

Although $S$. warneri can survive in presence or absence of oxygen, the environmental oxygen level determines the metabolism of this facultative bacterium (Wallace et al., 2016; Sanchez et al., 2019). The presence of diffusional limitations plays an important role in solid systems, so oxygen is the main factor to limit microbial growth in solid food. Different works have studied the mechanisms and conditions that determine the behaviour of facultative bacteria, mainly Listeria, in food environments with low oxygen concentration and solid systems. Specifically, Lungu et al. (2009) carried out a review on the effect of low oxygen and/or anaerobiosis in the growth, survival and proliferation of this pathogen in food. Listeria behaviour has been studied in different foodstuffs, such as cheese, chicken and fish and, in all cases, structure was a key parameter regarding this genus growth (Baka et al., 2017; Noriega et al., 2008, 2010b; Verheyen et al., 2018). Additionally, Aspridou et. al (2014) evaluated the growth of L. monocytogenes in gelling media and reported that pathogen's growth was lower in microstructured media, resulting in some cases in microbial growth suppression. The effect of oxygen availability and diffusional limitations on the genus Staphylococcus growing in food has been much less studied (Alonso et. al, 2021; Belay and Rasooly, 2002; Sanchez et al., 2019).

With the aim of knowing the effect of the availability of oxygen on the growth of $S$. warneri in the model pastry filling, in addition to the samples taken on the surface, samples of the bottom of the syringes were also obtained. As can be seen in Figure 1, the growth of $S$. warneri in all analysed temperatures was higher in the surface position than in the bottom position. After 48 hours of incubation the amount of CFU/g in the surface was almost one order of magnitude

Table 1. Maximum specific growth rate $\left(\mu_{\max }\right)$ values at the exponential phase of growth of $S$. warneri in model pastry filling at different temperatures and positions. In all cases $r^{2}>0.95$.

\begin{tabular}{ccc}
\hline Temperature & Longitudinal position & $\mu_{\max }\left(\mathrm{h}^{-1}\right)$ \\
\hline \multirow{2}{*}{$30^{\circ} \mathrm{C}$} & Surface & $0.0573^{a}$ \\
& Bottom & $0.0407^{b}$ \\
\hline \multirow{2}{*}{$20^{\circ} \mathrm{C}$} & Surface & $0.0438^{c}$ \\
& Bottom & $0.0242^{d}$ \\
\hline \multirow{2}{*}{$6^{\circ} \mathrm{C}$} & Surface & $0.0209^{e}$ \\
& Bottom & $0.0150^{f}$ \\
\hline Different letters indicate significant differences between groups $(p<0.05)$ \\
\hline
\end{tabular}

Universitas Scientiarum Vol. 26(2):229-242 
higher than values measured in the bottom in samples stored at $30^{\circ} \mathrm{C}$. However, in model pastry filling stored at $6^{\circ} \mathrm{C}$ the difference between surface and bottom was much lower. The lower $\mu_{\max }$ of Staphylococcus at this temperature implied a lower consumption rate of oxygen, so that the effect of diffusional limitations was less important for lower temperatures; probably, because temperature at this condition is a more limiting factor than oxygen availability. In Table 1, it can be observed that $\mu_{\max }$ values were in all cases higher for surface positions than for bottom positions. Diffusional limitations imply lower concentration of oxygen in the inner part of the food, which reduce the maximum specific growth rate of $S$. warneri. Nevertheless, the growth is not inhibited at any of the studied temperatures.

\subsection{Structural characterisation of the model food. Does the structure affect the microor- ganism growth?}

Rheological assays have been carried out in order to characterise the model pastry filling at different temperatures. In Figure 2 it is shown the values of storage $\left(G^{\prime}\right)$ and loss moduli $\left(G^{\prime \prime}\right)$ obtained from frequency sweeps at different temperatures, and in Table $\mathbf{2}$ it is shown the average values for $G^{\prime}$ and $G^{\prime \prime}$ and their corresponding average $\tan \delta$ values. ANOVA showed that there were statistically significant differences between the means of $G^{\prime}$ and $G^{\prime \prime}$, and the moduli values increased as temperature decreased, which indicates that the filling structure becomes stronger with lower temperatures. In all cases, since the storage modulus is much larger than the loss modulus, being $\tan \delta<1$, the elastic component dominates the rheological behaviour of the model pastry filling. The storage modulus increased slightly with increasing frequency

A)

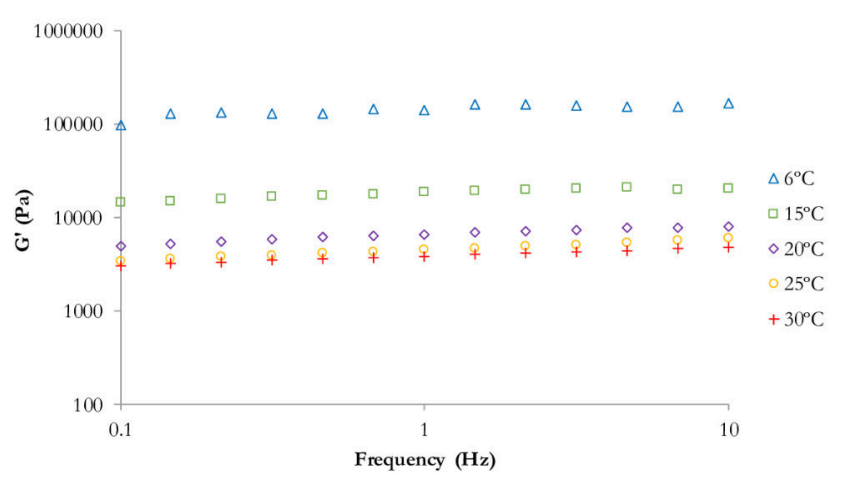

B)

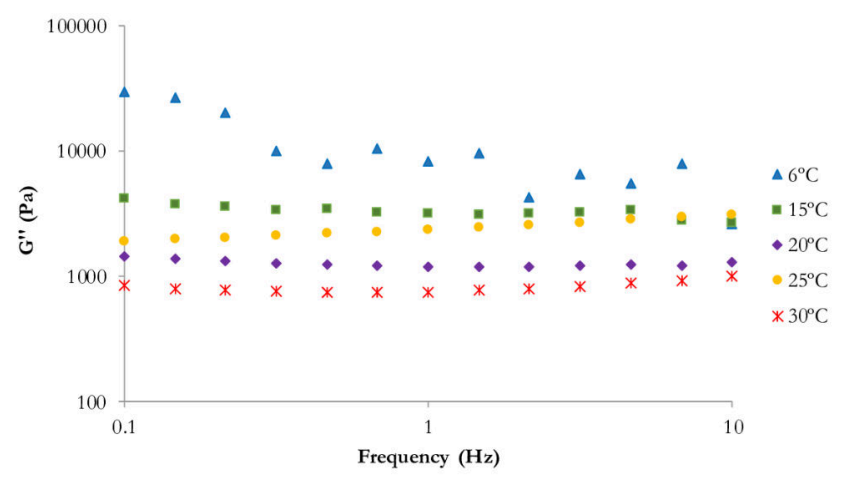

Figure 2. Rheological characterization of the model pastry filling: A) Storage modulus $\left(G^{\prime}\right)$ and B) Loss modulus $G^{\prime \prime}$ as a function of the angular frequency at $6^{\circ} \mathrm{C}, 15^{\circ} \mathrm{C}, 20^{\circ} \mathrm{C}, 25^{\circ} \mathrm{C}$ and $30^{\circ} \mathrm{C}$. 
Table 2. Rheological characterization of the model pastry filling obtained from frequency sweeps. Average values for storage modulus $\left(G^{\prime}\right)$, loss modulus $\left(G^{\prime \prime}\right)$ and their associated average standard deviations, and average $\tan \delta$ values.

\begin{tabular}{cccc}
\hline Temperature & $G^{\prime}(\mathrm{kPa})$ & $G^{\prime \prime}(\mathrm{kPa})$ & $\tan \delta$ \\
\hline $6^{\circ} \mathrm{C}$ & $143.8 \pm 19.3^{a}$ & $11.5 \pm 8.5^{a}$ & $0.0801^{a}$ \\
$15^{\circ} \mathrm{C}$ & $18.2 \pm 2.2^{b}$ & $3.3 \pm 0.4^{b}$ & $0.1824^{b}$ \\
$20^{\circ} \mathrm{C}$ & $6.6 \pm 1.0^{c}$ & $1.3 \pm 0.1^{c}$ & $0.1918^{c}$ \\
$25^{\circ} \mathrm{C}$ & $4.6 \pm 0.8^{d}$ & $2.4 \pm 0.4^{d}$ & $0.5317^{d}$ \\
$30^{\circ} \mathrm{C}$ & $3.9 \pm 0.5^{e}$ & $0.8 \pm 0.1^{e}$ & $0.2113^{e}$ \\
\hline
\end{tabular}

Different letters within columns indicate significant differences between groups $(p<0.05)$

for all the temperatures considered, which is a common behaviour of semi-solid fats and it is in accordance with results reported by other authors for different vegetal butters (Emadzadeh et al., 2013; Gregersen et al., 2015; Muresan et al., 2014). The values of the loss modulus remained also constant over the frequency range, except for the analysis carried out at $6{ }^{\circ} \mathrm{C}$. At this temperature, the value of $G^{\prime \prime}$ slightly decreased from $0.1 \mathrm{~Hz}$ to $0.5 \mathrm{~Hz}$ and from $0.5 \mathrm{~Hz}$ to $10 \mathrm{~Hz}$ values fluctuated between approximately $8000 \mathrm{~Pa}$ and $10000 \mathrm{~Pa}$. In general, the standard deviations associated with the average values of moduli increased with decreasing temperature, which reflected a less homogeneous structure at lower temperatures.

The differences observed in $G^{\prime}$ and $G^{\prime \prime}$ indicate that the food model structure notably varies depending on temperature. In addition, the frequency dependency may be originated by the result of interchain entanglements not having enough time to break or by the result of the small deformation mechanical working, causing structural changes in the fat samples (Gregersen et al., 2015). In order to obtain a more detailed information about structural modifications, frequency sweep tests data were fitted to equation 1, which is commonly used to characterise emulsions and gel foods (Gabriele et al., 2001; Laca et al., 2010b; Matos et al., 2018):

$$
G^{*}=A \cdot v^{1 / z}
$$

where $G^{*}$ is the complex modulus in $\mathrm{Pa}$, the frequency in $\mathrm{Hz}, z$ (dimensionless) the coordination number and $A$ ( $G^{*}$ in $\mathrm{Pa}$ at $\left.1 \mathrm{~Hz}\right)$ the proportional coefficient. The coordination number $(z)$ is a measure of the number of rheological units correlated with one another in the three-dimensional structure, whereas the proportional coefficient $(A)$ is related to the strength of the interaction between those units (Mancini et al., 2002).

Values of parameters $A$ and $z$ are shown in Table 3. The proportional coefficient value varied from $3.9 \mathrm{kPa}$ to $96.8 \mathrm{kPa} s^{1 / z}$, whereas the variation range of the coordination number was much narrower (10.2 to 14.3). In addition, and according to ANOVA results, there were statistically significant differences between the $A$ values, on the contrary, the $z$ values were not significantly different ( $95 \%$ confidence interval).

The value found for $A$ at $25^{\circ} \mathrm{C}$ was $4.7 \mathrm{kPa} s^{1 / z}$, much lower than that reported by Muresan et al. (2014) for different particle size of sunflower tahini at this temperature (104 $\mathrm{kPa} s^{1 / z}$ to $443 \mathrm{kPa}$ $s^{1 / z}$ ). On the contrary, the $z$ value was quite higher than that reported by the former authors (2.4 to 3.5). With respect to the network strength, a clear trend can be observed, since $A$ value raised when temperature decreased. Similar network extensions $(z)$ were found for $30^{\circ} \mathrm{C}, 25^{\circ} \mathrm{C}$ 
Table 3. Power-law parameters obtained from frequency sweeps. Average values \pm SD are reported. In all cases, except for $6^{\circ} \mathrm{C}, r^{2} \geq 0.91$.

\begin{tabular}{ccc}
\hline \multirow{2}{*}{ Temperature } & \multicolumn{2}{c}{ Power-law parameters } \\
\cline { 2 - 3 } & $A\left(\mathrm{kPa} s^{1 / z}\right)$ & $z$ \\
\hline $6^{\circ} \mathrm{C}$ & $96.8 \pm 65.3^{a}$ & $14.3 \pm 3.8^{a}$ \\
$15^{\circ} \mathrm{C}$ & $18.4 \pm 4.5^{b}$ & $13.6 \pm 1.6^{a}$ \\
$20^{\circ} \mathrm{C}$ & $6.6 \pm 1.3^{c}$ & $10.2 \pm 0.5^{a}$ \\
$25^{\circ} \mathrm{C}$ & $4.7 \pm 0.4^{d}$ & $10.8 \pm 2.4^{a}$ \\
$30^{\circ} \mathrm{C}$ & $3.9 \pm 2.4^{e}$ & $10.5 \pm 1.0^{a}$ \\
\hline \multicolumn{2}{c}{ Different letters within columns indicate } \\
\multicolumn{2}{c}{ significant differences between groups $(p<0.05)$} \\
\hline
\end{tabular}

and $20^{\circ} \mathrm{C}$, whereas the $z$ value slightly increased at $15^{\circ} \mathrm{C}$ and $6{ }^{\circ} \mathrm{C}$. Thus, in general, samples at lower temperatures show more aggregate structures and stronger links compared to those at warmer ones. These results are in agreement with those reported by Migliori et al. (2009) who analysed the effect of egg as ingredient in Yorkshire pudding batter. They found that parameter $z$ values were similar at $10^{\circ} \mathrm{C}$ and $30^{\circ} \mathrm{C}(2.4$ and 2.6 , respectively), whereas $A$ decreased from 21 to 12 at $10^{\circ} \mathrm{C}$ and $30^{\circ} \mathrm{C}$, respectively.

Rheological data indicated that the structure of the model pastry filling was very similar at $20^{\circ} \mathrm{C}$ and $30^{\circ} \mathrm{C}$, whereas it notably changed at $6{ }^{\circ} \mathrm{C}$ (see Figure 2 and Table 3 ). In order to go in depth about the possible effect of the structure over the growth rate of the bacterium, the maximum specific growth rates obtained at the different temperatures for the surface and bottom positions (Table 1) were fitted to an Arrhenius type equation (Peleg et al., 2012). When $\ln \mu_{\max }$ was depicted versus $1 / T$, the linear fitting was not very good for any of the two positions, with R-squared lower than 0.98 Figure 3). This suggests that the microorganism growth not only was affected by temperature and oxygen availability, but also by the confinement of the bacteria inside the structured media, which was formed by a network much stronger at $6^{\circ} \mathrm{C}$. In agreement with these results, Aspridou et. al (2014) reported that the microstructure of the medium could cause a decrease in the growth rate of Listeria monocytogenes. A complicated relation among temperature, composition and structural aspects of food model systems exists, as it was also indicated by Baka et al. (2017) who studied the behaviour of L. monocytogenes on fish-protein based model systems. 


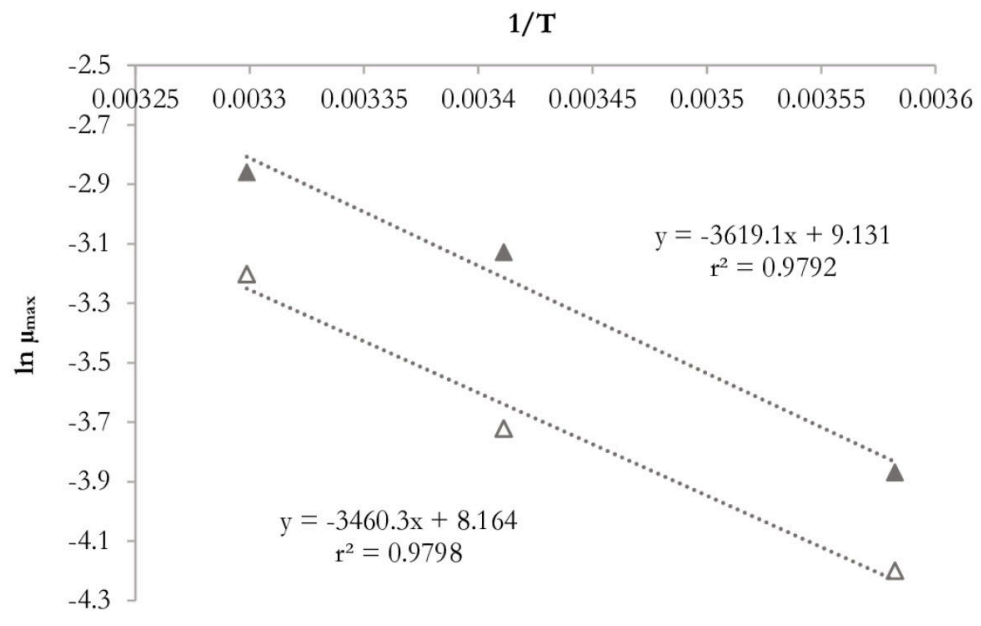

Figure 3. Fitting of the maximum specific growth rates of $S$. warneri (surface: $\triangle$ and bottom: $\triangle$ ) at different temperatures to an Arrhenius type equation: $\mu_{\max }$ in $\mathrm{h}^{-1}$ and $T$ in $\mathrm{K}$.

\section{Conclusions}

The growth of Staphylococcus in solid media was conditioned by oxygen diffusion and also by temperature, which was clearly reflected by the values obtained for the maximum specific growth rates at the exponential phase.

Frequency sweep results showed that the elastic component dominates the rheological behaviour of model pastry filling. In addition, $A$ and $z$ parameters indicated that the network strength increased when temperature decreased, whereas network extensions slightly increased at lower temperatures.

The values obtained for the $\mu_{\max }$ at different temperatures were fitted to an Arrhenius type equation. The moderate goodness of this fitting suggests that the structure of the model pastry filling exerted certain influence on the behaviour of Staphylococcus.

The results of this work revealed a complex relationship between system structure and other factors such as temperature and food model composition. A deep knowledge of this relationship would favour to obtain reliable predictions of the growth kinetics of bacteria in real food products, which could help to avoid the proliferation of undesirable or even pathogenic microorganisms in different foodstuffs.

\section{Acknowledgements}

This study was carried out thanks to funding from the Employment, Industry and Tourism Office of the Principality of Asturias (Spain) through project IDI/2018/000127.

\section{Conflict of interest}

The authors certify that they have no conflict of interest. 


\section{References}

Alhashimi HMM, Ahmed MM, Mustafa JM. Nasal carriage of enterotoxigenic Staphylococcus aureus among food handlers in Kerbala city, Karbala International Journal of Modern Science, 3: 69-74, 2017.

doi: doi: 10.1016/j.kijoms.2017.02.003

Alonso P, Laca A, Laca A, Diaz, M. Rheological characterisation of yolk-based gels and Staphylococcus growth, International Journal of Food Science and Technology, 2021, 56: 1741-1749. doi: 10.1111/ijfs.14799

Ananou S, Rivera S, Madrid MA, Maqueda M, Martínez-Bueno M., Valdivia. Application of enterocin AS-48 as biopreservative in eggs and egg fractions: Synergism through lysozyme, LWT-Food Science and Technology, 89: 409-417, 2018.

doi: 10.1016/j.lwt.2017.11.018

Aspridou Z, Moschakis T, Biliaderis CG, Koutsoumanis KP. Effect of the substrate's microstructure on the growth of Listeria monocytogenes,Food Research International, 64: 683-691, 2014. doi: 10.1016/j.foodres.2014.07.031

Baka M, Vercruyssen S, Cornette N, Van Impe JF. Dynamics of Listeria monocytogenes at suboptimal temperatures in/on fish-protein based model systems: Effect of (micro) structure and microbial distribution, Food Control, 73: 43-50, 2017.

doi: 10.1016/j.foodcont.2016.06.031

Baptista I, Rocha SM, Cunha A, Saraiava JA, Almeida A. Inactivation of Staphylococcus aureus by high pressure processing: An overview, Innovative Food Science \& Emerging Technologies, 36: 128-149, 2017.

doi: 10.1016/j.ifset.2016.06.008

Belay N, Rasooly A. Staphylococcus aureus growth and enterotoxin a production in an anaerobic environment, Journal of Food Protection, 65: 199-204, 2002.

doi: 10.4315/0362-028x-65.1.199

Chinyama K. Institutions involved in Food Safety: National Industry Organizations - Case of UK Food and Drink Federation. Encyclopedia of Food Safety, vol 4, 373-378 pp., 2014.

Costello KM, Gutierrez-Merino J, Bussemaker M, Ramaioli M, Baka M, Van Impe JF, Velliou EG. Modelling the microbial dynamics and antimicrobial resistance development of Listeria in viscoelastic food model systems of various structural complexities, International Journal of Food Microbiology, 286: 15-30, 2018.

doi: 10.1016/j.ijfoodmicro.2018.07.011

Emadzadeh B, Razavi SMA, Schleining G. Dynamic rheological and textural characteristics of low-calorie pistachio butter, International Journal of Food Properties, 16: 512-526, 2013. 10.1080/10942912.2011.553758

Gabriele D, de Cindio B, D’Antona P. A weak gel model for foods, Rheologica Acta, 40: 120-127, 2001.

$10.1007 / \mathrm{s} 003970000139$

Universitas Scientiarum Vol. 26(2):229-242

http://ciencias.javeriana.edu.co/investigacion/universitas-scientiarum 
Gregersen SB, Miller RL, Hammershøj M, Andersen MD, Wiking L. Texture and microstructure of cocoa butter replacers: Influence of composition and cooling rate, doi: Food Structure, 4: $2-15,2015$.

doi: 10.1016/j.foostr.2015.03.001

Laca A, Paredes B, Díaz M. A method of egg yolk fractionation. Characterization of fractions, Food Hydrocolloids, 24: 434-443, 2010a.

doi: 10.1016/j.foodhyd.2009.11.010

Laca A, Sáenz, MC, Paredes B, Díaz M. Rheological properties, stability and sensory evaluation of low-cholesterol mayonnaises prepared using egg yolk granules as emulsifying agent, Journal of Food Engineering, 97: 243-252, 2010b

doi: 10.1016/j.jfoodeng.2009.10.017

Lungu B, Ricke SC, Johnson MG. Growth, survival, proliferation and pathogenesis of Listeria monocytogenes under low oxygen or anaerobic conditions: A review, Anaerobe, 15: 7-17, 2009.

doi: 10.1016/j.anaerobe.2008.08.001

Mancini F, Montanari L, Pressini D, Fantozzi P. Influence of alginate concentration and molecular weight on functional properties of mayonnaise, LWT-Food Science and Technology, 35: 517-525, 2002.

doi: $10.1006 /$ fstl.2002.0899

Matos M, Laca A, Rea F, Iglesias O, Rayner M, Gutiérrez G. O/W emulsions stabilized by OSA-modified starch granules versus non-ionic surfactant: Stability, rheological behaviour and resveratrol encapsulation, Journal of Food Engineering, 222: 207-217, 2018.

doi: 10.1016/j.jfoodeng.2017.11.009

Migliori M, Gabriele D, Baldino N, Lupi FR, De Cindio B. Rheological properties of batter dough: Effect of egg level, Journal of Food Process Engineering, 34: 1266-1281, 2009.

doi: 10.1111/j.1745-4530.2009.00410.x

Muresan V, Danthine S, Racolta E, Muste S, Blecker C. The influence of particle size distribution on sunflower tahini rheology and structure, Journal of Food Process Engineering, 37: 1745-4530, 2014.

doi: 10.1111/jfpe.12097

Peleg M, Normand MD, Corradini, MG. The Arrhenius equation revisited, Critical Reviews in Food Science and Nutrition, 52: 830-851, 2012.

doi: 10.1080/10408398.2012.667460

Noriega E, Laca A, Díaz M. Modelling of diffusion-limited growth for food safety in simulated cheeses, Food and Bioproducts Processing, 86: 122-129, 2008.

doi: 10.1016/j.fbp.2008.03.005

Noriega E, Laca A, Díaz M. Development of a structure-based model for the competitive growth of Listeria innocua in minced chicken breasts, International Journal of Food Microbiology, 142: 44-52, 2010a.

doi: 10.1016/j.ijfoodmicro.2010.05.025

Noriega, E., Laca, A., Díaz, M. Decisive role of structure in food microbial colonization and implications for predictive microbiology, Journal of Food Protection, 73: 938-951, 2010b. doi: $10.4315 / 0362-028 X-73.5 .938$ 
Rebouças LT, Santiago LB, Martins LS, Rios Menezes AC, Araújo MDPN, Almeida RCDC. Food safety knowledge and practices of food handlers, head chefs and managers in hotels' restaurants of Salvador, Brazil, Food Control, 73: 372-381, 2017.

doi: 10.1016/j.foodcont.2016.08.026

Sanchez M, Neira C, Laca A, Laca A, Diaz M. Survival and development of Staphylococcus in egg products, LWT-Food Science and Technology, 101: 685-693, 2019. doi: 10.1016/j.lwt.2018.11.092

Silva SS, Carvalho JWP, Aires CP, Nitschke M. Disruption of Staphylococcus aureus biofilms using rhamnolipid biosurfactants, Journal of Dairy Science, 100: 7864-7873, 2017. doi: $10.3168 /$ jds.2017-13012

Verheyen D, Bolívar A, Pérez-Rodríguez F, Baka M, Skåra T, Van Impe JF. Effect of food microstructure on growth dynamics of Listeria monocytogenes in fish-based model systems, International Journal of Food Microbiology, 283: 7-13, 2018.

doi: 10.1016/j.ijfoodmicro.2018.05.032

Wallace N, Zani A, Abrams E, Sun Y. The impact of oxygen on bacterial enteric pathogens, Advances in Applied Microbiology, 95: 179-204, 2016.

doi: 10.1016/bs.aambs.2016.04.002 
Efectos acoplados de la estructura, disponibilidad de oxígeno y temperatura en el crecimiento microbiano del relleno de pastelería

Resumen: La estructura de los alimentos es un factor clave a considerar con miras a controlar el crecimiento microbiano. Se empleó un relleno de pastelería como alimento modelo para estudiar el crecimiento de Staphylococcus bajo diferentes condiciones. Además, la estructura del sistema se caracterizó con base en mediciones reológicas. Los barridos de frecuencia mostraron que, en todos los casos, el componente elástico determina el comportamiento reológico del relleno de pastelería usado como modelo $\left(G^{\prime}>G^{\prime \prime}\right)$. Los valores obtenidos para el número de coordinación $(z)$ y el coeficiente proporcional $(A)$ indicaron que el alimento modelo exhibe más estructuras de agregados y enlaces más fuertes a temperaturas más bajas. De acuerdo con las máximas tasas de crecimiento específico, el crecimiento de Staphylococcus en el modelo de pastelería estuvo claramente condicionado por la difusión de oxígeno, que está limitada por la matriz del alimento y también por la temperatura de incubación. Además, el análisis del crecimiento de Staphylococcus a distintas temperaturas sugirió la influencia de la estructura del relleno de pastelería en el comportamiento del microrganismo.

Palabras Clave: microorganismos; inocuidad de los alimentos; pastelería; reología; Staphylococcus; estructura

Efeitos de acoplamento entre a estrutura, a disponibilidade de oxigénio e a temperatura no crescimento microbiano em recheio de pastelaria

Resumo: A estrutura dos alimentos é um fator chave a se considerar para controlar o crescimento microbiano. Neste estudo, utilizamos recheio de pastelaria como alimento modelo para estudar o crescimento de Staphylococcus em diferentes condições. Adicionalmente, caracterizamos a estrutura do sistema alimentar mediante medições reológicas. As varreduras de frequência mostraram que, em todos os casos, o componente elástico determinou o comportamento reológico do recheio de pastelaria utilizado como modelo $\left(G^{\prime}>G^{\prime \prime}\right)$. Os valores obtidos para o número de coordenação $(z)$ e o coeficiente proporcional $(A)$ indicaram que o alimento modelo apresenta mais estruturas de agregados e uniões mais fortes a temperaturas mais baixas. Segundo as taxas de crescimento específicas máximas, o crescimento de Staphylococcus no receio de pastelaria modelo esteve claramente condicionado pela difusão do oxigénio, que é limitada pela matriz do alimento e pela temperatura de incubação. Adicionalmente, a análise de crescimento de Staphylococcus a diferentes temperaturas sugeriu que a estrutura do recheio de pastelaria influencia o comportamento dos microrganismos.

Palavras-chave: microorganismos; segurança alimentar; pastelaria; reologia; Staphylococcus; estrutura. 
Mario Díaz He is Professor of Chemical Engineering at the University of Oviedo since 1987. He has been the main researcher of the group "Technology of Bioprocesses and Reactors" (TBR) for almost 40 years. During his career, he has carried out more than 80 contracts with different companies for industrial design, process analysis and development. He is author of more than 400 scientific and technological articles and he has seven patents.

ORCID: 0000-0001-6218-1140

Adriana Laca She is Lecturer of Environmental Technology Engineering at the University of Oviedo since 2010. She has supervised $5 \mathrm{PhD}$ Thesis and she is author of more than 70 scientific and technological articles. Her research interest includes food safety, valorisation of food wastes, environmental management and wastewater treatment. She is member of the "Mesa Española de Tratamiento de Aguas".

ORCID: 0000-0001-5665-4466

Amanda Laca She is Assistant Professor of Environmental Technology Engineering at the University of Oviedo since 2019. She is PhD by the University of Oviedo and has a Master in Food Biotechnology. She has published more than 40 scientific and technological articles, she is author of 36 communications to congresses and conferences and she has one patent.

ORCID: 0000-0002-8508-8173

Paula Mateos She has degree in Biology by the University of Salamanca and a Master's Degree in Food Biotechnology by the University of Oviedo. Currently, she is working as laboratory quality technician in a multinational coffee enterprise.

ORCID: 0000-0002-3452-5636 